\title{
37. Toplumsal cinsiyet açısından Saç Adağı: Kara İyeleri kandırmak ${ }^{1}$
}

\section{Emine ÇAKIR²}

APA: Çakır, E. (2021). Toplumsal cinsiyet açısından Saç Adağı: Kara İyeleri kandırmak. RumeliDE Dil ve Edebiyat Araştırmaları Dergisi, (23), 583-593. DOI: 10.2900o/rumelide.949492.

\section{$\ddot{\mathbf{O} z}$}

Toplumsal cinsiyet; bireyin doğuştan getirdiği biyolojik, fizyolojik ve genetik özellikleri ifade eden cins kavramının dışında doğduğu toplumda kendisine öğretilen beklendik ve istendik kültürel stereotip davranış, rol, görünüm ve sorumlulukları ifade eden bir kavramdır. Bu çalışmada, geçiş dönemlerinden doğum geleneği özelinde, genellikle erkek çocuğu doğmayan ya da uzun süre yaşamayan ailelerin çocuklarını yaşatmak için başvurduğu inanç ve ritüellerden biri olan saç adağ âdeti, toplumsal cinsiyet ve ritüel ilişkisi kapsamında incelenmiştir. Türk kültüründe çocuğa bazı koruyucu adların verilmesi, çocuğun türbeye adanması ya da başkasına satılması ritüeline rastlanır. Bu pratikle, Şamanizm'e göre bireye ve tabiata zarar verdiğine inanılan kötü ruhlardan bir başka ifadeyle kara iyelerden, yaşam eşiği olarak görülen yedi yaşına kadar, çocuğun korunarak yaşaması amaçlanır. Pratiği, toplumsal cinsiyet odağında tartışmaya değer kılan ise erkek çocuğun yaşaması için "kız çocuğu gibi” saçının uzatılmasıdır. Çalışmada, türbeye adanan fakat yedi yaşına girdiği hâlde maddi imkansızlıklar nedeniyle saçı ve kurbanı kesilemeyen, toplumsal cinsiyet algısına aykırı görünümü nedeniyle medyada gündeme gelen bir örnekleme yer verilmiştir. Zira geleneğin varlığı ya da sorgulanması bağlamla doğrudan ilgilidir. Sorgulanan gelenek, zamanın ve bağlamın ruhuna yanıt vermiyor, herkes tarafından bilinmiyorsa ister istemez "Bu ne biçim gelenek", "Böyle gelenek olmaz olsun" ya da "Bu zamanda böyle âdetler mi kalır?" gibi protest söylemi de beraberinde getirmektedir. Geleneğin reddi doğal olarak, geleneği besleyen dinamiklerin ortadan kalkmasına neden olmaktadır. Çocuksuzluk olgusuyla iç içe olan bu ritüelde, günümüzde geleneğin herkes tarafından bilinmemesi, iletişim teknolojisinin gelişmesi, çocuksuzluk durumunda modern tıbba başvurulması, kentleşme, çocuk gelişimi hakkındaki farkındalık gibi birçok etken, geleneğin sorgulanmasına ve eleştirilmesine neden olmakta ve konuyu toplumsal cinsiyet tartışmaları odağına taşımaktadır.

Anahtar kelimeler: Halkbilimi, toplumsal cinsiyet, ritüel, saç adă̆ı, adak, kara iye

\section{Hair vote in terms of social gender: Bad spirits fooling}

\begin{abstract}
Gender; Apart from the concept of genus, which expresses the biological, physiological and genetic characteristics that an individual is born with, it is a concept that expresses the expected and desired cultural stereotype behavior, role, appearance and responsibilities that are taught to him in the society he was born. In this study, the tradition of hair sacrifice, which is one of the beliefs and rituals used by families who do not have a boy or who do not live for a long time, to keep their children alive, was examined within the context of gender and ritual relationship. In Turkish
\end{abstract}

Bu çalışma, 20-22 Mart 2015 tarihinde Ankara'da Orta Doğu Teknik Üniversitesi'nde düzenlenen Toplumsal Cinsiyet ve Halk Kültürü Sempozyumu'nda sunulmuş bildirinin gözden geçirilmiş ve düzenlenmiş biçimidir.

Dr. Öğr. Üyesi, Ankara Hacı Bayram Veli Üniversitesi, Edebiyat Fakültesi, Türk Halk Bilimi Bölümü (Ankara, Türkiye), eminecakir.thb@gmail.com, ORCID ID: 00oo-0003-2196-5592 [Araştırma makalesi, Makale kayıt tarihi: 28.02.2021kabul tarihi: 20.06.2021; DOI: 10.29000/rumelide.949492]

Adres $\mid$ Address

RumeliDE Dil ve Edebiyat Araşttrmalar Dergisi $\quad$ RumeliDE Journal of Language and Literature Studies Osmanağa Mahallesi, Mürver Çiçeği Sokak, No:14/8 Osmanağa Mahallesi, Mürver Çiçeği Sokak, No:14/8

Kadıköy - İSTANBUL / TÜRKIYE 34714 Kadıköy - ISTANBUL / TURKEY 34714 e-posta: editor@rumelide.com

e-mail: editor@rumelide.com,

tel: +90 505 7958124, +90 216773 o 616 phone: +90 505 7958124, +90 2167730616 
culture, some protective names are given, dedicated to the shrine or a ritual of selling to someone else. With this practice, it is aimed to protect the child from the evil spirits believed to harm the individual and nature according to Shamanism, in other words, to the age of seven, which is seen as the threshold of life. What makes the practice worth discussing in the focus of gender is the lengthening of the "girl-like" hair for the boy to live. In the study, a sample that is dedicated to the tomb, but whose hair and victims cannot be cut due to financial difficulties even when they reach the age of seven, and that came to the fore in the media due to its appearance against gender perception, is included. Because the existence or questioning of tradition is directly related to the context. If the questioned tradition does not respond to the spirit of the time and the context, if it is not known by everyone, inevitably, "What kind of tradition is this", "No such tradition" or "Do such customs remain at this time?" protest discourse also brings with it. The rejection of tradition naturally causes the dynamics that nourish tradition to disappear. In this ritual, which is intertwined with the phenomenon of childlessness, many factors such as the fact that tradition is not known by everyone today, the development of communication technology, the application of modern medicine in the case of childlessness, urbanization, awareness of child development, cause questioning and criticism of the tradition and bring the issue to the focus of gender debates.

Keywords: Folklore, gender, hair vow, bad spirit

\section{Giriş}

Kadın ya da erkek olmak, dünyanın her yerinde biyolojik bir durumken "erkeklik" ve "kadınlık" olgusu bireyin doğduğu ve yaşadığı toplumda kendisine öğretilir, hâliyle bu olgu kültürler arası benzerlik ve farklılık gösterir. Toplumsal cinsiyet kavramı, bireyin doğuştan getirdiği biyolojik, fizyolojik ve genetik özelliklerini ifade eden cins kavramının dışında bireyin doğduğu toplumda kendisine sonradan öğretilen stereotip davranış, görünüm, rol ve sorumluluklarını ifade eder.

Toplumsal cinsiyete dayalı roller ise tıpkı cinsiyete odaklanan görünüm gibi kültüreldir. 20. asrın ikinci yarısında ortaya çıkan ve disiplinler arası farklı alanlarda da kullanılan bu kavram, birçok tartışmayı da beraberinde getirmiştir. Halkbilimi alanında toplumsal cinsiyet kavramıyla ilgili çalışmaların özellikle gelenek, ritüel ya da ninni, masal gibi sözlü kültür ürünlerine odaklı incelendiği görülmektedir. Ritüel ve toplumsal cinsiyet ilişkisinin sorgulandığı bu çalışmada, geçiş dönemlerinden ilki olan doğumda çocuksuzluğa bağlı olarak, kanlı ve kansız kurban ritüelini içinde barındıran saçı âdeti üzerinde durulmuştur. Toplumsal cinsiyetin kültüre bakan boyutu, bireyin erkek ya da kız olduğunu belirleyen giydiği kıyafetin biçiminden rengine, bedenindeki organlara uyguladığı (oje sürmek, kına yakmak, küpe takmak, saçı uzatmak gibi) eylemlerden jest ve mimiğe kadar birçok alanda kendini gösterir. Bireyin aksi eylem ve görünümü ise toplumsal mekanizmalar ve normlar tarafından denetlenir. Aykırı kişiler ise marjinal kabul edilerek ötekileştirilir, toplum tarafından istendik davranış ve görünüm sergilemek üzere yönlendirilir.

Toplumsal cinsiyet kavramını terminolojiye kazandıran Ann Oakley'e göre "cinsiyet”; (sex) biyolojik erkek ve kadın ayrımını anlatırken, "toplumsal cinsiyet" (gender) erkeklik ile kadınlık arasındaki buna paralel ve toplumsal bakımdan eşitsiz bölünmeye gönderme yapmaktadır (Marshall, 1999: 98). Maruani, "Erkek ya da kadın olarak doğulmaz, erkek ya da kadın olunur" (2011: 795) sözüyle erkeklik ya da kadınlığa ait stereotiplerin içine doğulan toplumda bireye sonradan öğretildiğini vurgular. "Her toplumda mevcut kültürel yapı içerisinde 'Kadın ve erkek nasıl davranır, nasıl giyinir? Kadınlara ve erkelere özgü alışkanlıklar ve uğraşılar nelerdir?’ gibi soruların farklı yanıtları vardır. Kültürel yapının

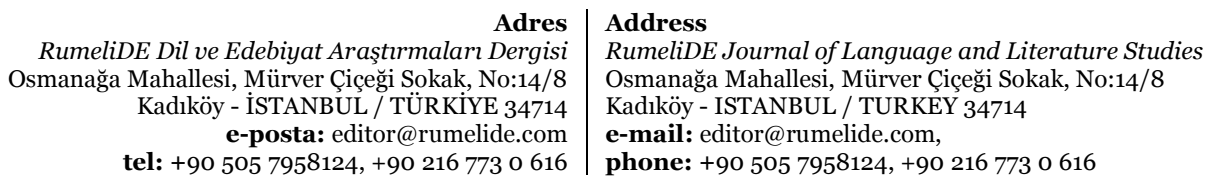


vermiş olduğu bu cevap farklılıkları aynı zamanda cinsiyetlerin toplum içerisindeki konumlanışına ve şekillenmesine de etki ederek bir farklılık doğurur. Kültürün cinsiyetlere yönelik bölümü, bir toplumda 'cinsiyet kültürü' nü oluşturur" (Ersoy, 2009: 214). Kenny ve Smillie, "Cinsiyetin biyolojik bir mesele olduğu ve toplumsal cinsiyetin ise toplumsal olarak kurgulanmış ve cinsiyetin biyolojik 'olgusu' ile bir şekilde bağlantılı bir dizi yerel düşünce olduğunu" (2017: 196) savunur. Bates ise yapıtının cinsiyetin toplumlaşması başlığı altında "Cinsiyetin toplumsallaşması çocuk doğar doğmaz başlar ve cinsler arasında sistemli bir eşitsizlik yaratır. Bireyler uygun ya da beklenen ve kabul edilebilen davranış açısından toplumsal cinsiyet kimliğinin ne olduğuna ilişkin fikirlerini büyük ölçüde bu süreç içinde oluşturur" (2013: 320-322) derken cinsler arası eşitsizliğe değinir. Türköne, "Cinsiyet kültürü" kavramını biyolojik cinsler üzerine sosyal-kültürel olarak inşa edilen "cinsiyet" olgusunun çok yönlü ifadesi (Türköne, 1995: 13) olarak açıklar. "Bir toplumda yer alan 'kadınlık' ve 'erkeklik' tanımları ve bunlara ilişkin imajlar, stereotipler, bunlara atfedilen özellikler; cinsiyet rol ve statüleri, davranış kalıpları, cinsiyete dayalı iş bölümü; cinsiyet kimlikleri ve bunların oluşum süreçleri (sosyalleşme); cinsler arası ilişkilerin düzenlenme biçimleri; evlenme âdetleri ve aile tipleri; cinslerin birbirine karşı tutumları, cinsel ahlâk, aşk ve güzellik anlayışları o toplumun cinsiyet kültürünü meydana getirir" (Türköne, 1995: 14). Berktay ise, toplumsal cinsiyeti; biyolojik cinsiyetten farklı olarak toplumsal ve kültürel olarak belirlenen ve dolayısıyla içeriği toplumdan topluma olduğu kadar tarihsel olarak da değişebilen "cinsiyet konumu" ya da "cins kimliği” olarak (2014: 16) tanımlar. Susser ise bir toplumun, bir çözümleme kategorisi olarak toplumsal cinsiyet unsurunu hesaba katmaksızın anlayabilmek mümkün olmadığını; aynı zamanda toplumsal cinsiyetin kendisi de kültürel ve tarihsel bir bağlam gerektirdiğini (Susser'den akt. Bates 2013: 318) söyleyerek benzer görüşleri dile getirir. Bektay (2014: 16), "toplumsal olarak verilmiş kadınlık ve erkeklik kalıpları ve imgelerinin varoluşumuz açısından can alıcı bir önem taşıdığını; bu imgelerin, dinlerin ve kültürlerin uzun yıllar boyunca oluşturduğu geleneklerin hem ürünü hem de parçası olduğunu" vurgularken toplumsal cinsiyetin ayrıca din ve kültür ilişkisine değinir. Eriksen ise "Uygulamada, cinsiyet farklılıkları sosyal ve kültürel olarak inşa edilmiş ve kurumsallaştırılmışlardır ve antropologlar genellikle, bu açıdan var olan farklılıklar üzerine yoğunlaşmakta ve cinsiyet tabirini kullanarak (biyolojik) cins ile bir ayrıma gitmektedir. Bununla birlikte erkek ile kadın arasındaki ilişki biçimlerinde önemli değişkenlikler görülür ve bu nedenle, cinsiyet hakkında bir genellemeye gitmek zordur" (2012: 203) derken aslında bu kavram etrafindaki tartışmalara dikkat çeker. Görüldüğü üzere doğuştan gelen biyolojik durum, cins kavramıyla açıklanması araştırmacılarca genel kabul iken toplumun bu cinslere yüklediği anlam, kültürel olarak toplumsal cinsiyet kavramıyla ifade edilmekte ve tarih, din, kültür gibi sosyal bilimlerle ilişkisi ve bağlılığı vurgulanmaktadır. Ayrıca çocuklarda toplumsal cinsiyet kimliğinin daha küçük yaşlardan itibaren doğdukları toplumda sonradan kendilerine öğretildiği ifade edilmektedir.

Türk toplumunda cinsiyet ve toplumsal cinsiyet bakış açısını inanç, gelenek, görenek gibi ritüellerde atasözü-deyim, masal, ninni, türkü gibi birçok sözlü kültür ürünlerinde görmek mümkündür: "Ye tatlıyı doğur Hakkı'yı, ye ekşiyi doğur Ayşe’yi, kız yükü, tuz yükü, kızın var mı derdin var, oğlanı her karı doğurmaz er karı doğurur, oğlan olsun deli olsun ekmek olsun kuru olsun, kadının saçı uzun aklı kısa olur" gibi deyim ve atasözlerinde ataerkil söylem dikkat çeker. Örnek, bu kavramı babaerki olarak ifade eder ve "Otoritenin, akrabalığın, evliliğin baba soy zincirine göre sıkı bir biçimde düzenlendiği toplumsal yapı" (2017: 38) olarak tanımlar, soy ve süreklilik söz konusu olduğundan cins özelinde erkek çocuk, buna bağlı olarak ister istemez kültürel bellekte önem taşır. Örnek’in Geleneksel Kültürümüzde Çocuk adlı eserinde kaynak kişilere yönelttiği "Çocuğunuzun erkek ya da kız olmasını istiyorsanız, doğumdan önce ne gibi pratiklere başvurursunuz?” sorusuna verilen yanıtlar ataerkil yapının bir izdüşümü olarak değerlendirilmelidir: "Kızlar makbul olmadığı için bir şey yapılmaz”, "Biz kızı sevmeyiz. Olursa olur, olmazsa aramayız", "Kız da neymiş... Oğlan çocuk daha iyi...”, "Kız çocuğun

\section{Adres $\mid$ Address}

RumeliDE Dil ve Edebiyat Araşttrmaları Dergisi $\quad$ RumeliDE Journal of Language and Literature Studies Osmanağa Mahallesi, Mürver Çiçeği Sokak, No:14/8 Osmanağa Mahallesi, Mürver Çiçeği Sokak, No:14/8 Kadıköy - İSTANBUL / TÜRKIYE 34714 Kadıköy - ISTANBUL / TURKEY 34714 e-posta: editor@rumelide.com tel: +90 505 7958124, +90 2167730616 phone: +90 505 7958124, +90 2167730616 
peşine kimse düşmez.", "Kız çok sevmeyiz ki doğurmak için çareler arayalım. Kız elalemin ocağını tüttürür, bizim ocağımızı oğlan çocuğu tüttürür. Bizde kız tüketici, sömürücü olarak görülür" (Örnek, 1979: 55-56). Buradan hareketle cinsiyete yönelik bakış açısının henüz birey dünyaya gelmeden daha anne karnındayken başladığı, toplum belleğinde belli stereotiplerle mevcut olduğu söylenebilir. Fakat bu durum toplumsal cinsiyet kavramından ziyade, ataerkil sistemin cinse bağll gerekliliği şeklinde yorumlanabilir. Fakat günümüzde bu algının yavaş yavaş değişmeye başladığı da vurgulanmalıdır.

Çalışmada ele alınan saç adağı ritüeli de bu bağlamda hem cinsiyet hem toplumsal cinsiyet kavramı etrafında tartışılmıştır. Özellikle erkek çocuğu doğup da yaşamayan ailelerin başvurduğu bu pratikte, çocuk türbeye ya da yatıra adanır. Yedi yaşına kadar saçı kesilmeyen çocuk, yedi yaşına girdiği zaman türbeye gidilir, türbede dua edilir, kurban kesildikten sonra saçları kesilerek ritüel tamamlanır. Çocuğun İslamî forma göre ölüm meleği Azrail'den, Şamanizm'e göre ise kara iyeler/ruhlardan korunması yönüyle ritüelin senkretik bir yapı arz ettiği söylenebilir. Emiroğlu ve Aydın'da göre senkretizm; kültürel görüngülerin analizinde, çoğu zaman birbirine yabancı (hatta kimi durumlarda karşıt) inanç ögelerini ya da ritüelleri ahenkleştirme girişimi, "karışma", "melezleşme", "kaynaşma" anlamlarına gelecek şekilde kullanılan analitik bir araçtır (2020: 942). Bu bağlamda özünde Şamanik olan saç adağının İslamî formla harmanlandığı ifade edilebilir.

Yedi sayısının da mitik ritüelistik bir rakam olması da etkenlerden biridir. 3 Saçın yedi yıl boyunca kesilmemesi kansız kurban ritüeli iken, türbeye adanan koç, koyun gibi hayvanlar ise kanlı kurban ritüelinin bir parçasıdır. Erkek çocuğun saçlarının yedi yıl boyunca kesilmemesi konunun toplumsal cinsiyet odaklı tartışma gerekçesidir, zira kızın saçının uzun, erkeğin kısa olması gerekliliği sonradan öğrenilen/öğretilen biçimsel bir davranış kalıbıdır. Ritüelde ataların ruhunu memnun ederek çocuğu kötü iyelerden/ruhlardan korumak esastır. P. Ergun’a göre "Eski Türklerin Tengri inancı kapsamında değerlendirilmesi gereken iyeleri, genel anlamda 'Bir şeyin koruyucu ruhu ve içindeki gizli güç, sahip, mâlik ve hâmi ruh' olarak algılanmaktadır. Yaradılışın başından beri var olduğuna inanılan iyeler, Sibirya destanlarına yansıdığı üzere işler yolunda gitmediğinde, sahibi olarak görevli oldukları yerle ilgili kaos ortamında hem durumu Tanrı'ya bildirerek şikâyet etmekte hem de Tanrı'nın bu konudaki emir ve yasaklarını bahadırlara iletmektedir. Bu roller, onların Tanrı tarafından görevlendirildiğinin göstergesi şeklinde düşünülmelidir” (2019: 17). Tengricilik inancındaki bu iye kavramı, Türklerde İslâm inancındaki "melek" kavramıyla bütünleşmiş ve İslamî bir kimliğe bürünerek yaşamaya devam etmiştir (Ergun, 2019: 17). İyelerin bazıları melekler gibi iyi karakterlidir; iyilik yapar; yardımseverdir; her türlü zenginlik sunabilir; dostluk ilişkisi kurabilir. Bazıları ise kötü cinler gibi kötü karakterli olup zarar verebilir (Ergun, 2019: 389). Görüleceği üzere iyi iyeler, İslamiyetteki meleklerin görevini üstlenmektedir. Ayrıca şeytanının cin olduğu göz önünde tutulduğunda; ak iyeler meleğin, kara iyeler şeytanın karşllığı olarak değerlendirilebilir.

İyelerin koruyucu güce sahip olması ve onlara kurbanlar sunulması eski Türk inanışında mevcuttur. "İyelere ve hami ruhlara sahip oldukları şeyleri korumaları ya da korumaktan vazgeçmemeleri için kurban sunulması, Türk dünyasında karakteristik bir özelliktir. İyelere sunulan kurbanlık hayvanlara ıtık denilir. Kurban kanlı veya kansız olabilir" (Ergun, 2019: 395). Türkler ata ruhlarını, muhtelif fonksiyonlar yüklenen iyeleri, Tengri'yi memnun etmek, onun rızasını kazanmak, yardımını sağlamak, istediklerini ona kabul ettirmek için kurban keserler ve saçı yaparlardı (İnan, 1976: 46-54). Çocuğu olmayanlar, çoğunlukla adak kurbanlar keser. Bu tür adak kurbanlar ziyaret edilen bir yatır için

$3 \quad$ Farklı kültürlerde yedi sayısının bolluk ve bereketle ilgili mistik inanışı için bakınız (Schimmel, 200o: 140-168). "Türk boylarının pek çok anlatısında, kabul ve davranışında karşılaşılan yedi sayısı, genellikle mitolojik inanışların etkisiyle kutsal saylmaktadır" (Aydın, 2019: 217).

Adres
RumeliDE Dil ve Edebiyat Araştırmaları Dergisi Osmanağa Mahallesi, Mürver Çiçeği Sokak, No:14/8 Kadıköy - İSTANBUL / TÜRKIYE 34714 e-posta: editor@rumelide.com tel: +90 $5057958124,+902167730616$
Address

RumeliDE Journal of Language and Literature Studies

Osmană̆a Mahallesi, Mürver Çiçeği Sokak, No:14/8

Kadıköy - ISTANBUL / TURKEY 34714

e-mail: editor@rumelide.com,

phone: +90 $5057958124,+902167730616$ 
yardımcı olması inancı ile kesilir (Kalafat, 1996: 111). Buradan hareketle ölen ruhların koruyucu olduğuna dair inanış ve iyeleri memnun etme düşüncesiyle onlara kurban sunma ve çocuksuzluk arasında kurulan ilişkinin Şamanik kökenli olduğu anlaşılmaktadır.

Saçı geleneği de bu bağlamda kansız kurban olarak değerlendirilebilir. "Saçı eskiden muhtelif olağanüstü güçlere sahip olduğuna inanılan iye ve ruhlara sunulan ve onlar adına onların rızasını ve yardımını kazanmak için dağıtılan cansız nesnelere/yiyecek, içecek, bez gibi verilen addır" (İnan, 1976: 345-415). Saçı sadece düğünlerde değil, hayatın her safhasında görülür. Çocuk dünyaya gelince, ilk dişi çıkınca, ilk defa traşı olunca ailesi 'saçı' yapar. Ayrıca ölen kişinin de ailesi saçlar yapar. Saçı giderek 'sadaka' ile özdeşleşmiştir (Kalafat, 1996: 111). Gebelik oluştuktan sonra da atanın görevi bitmez. Yeni doğanı gözetmek de onun işidir (Durkheim, 2019: 363). İnsan çevresinde olup biten olaylara sebep ararken atalarının ruhlarının bu olaylarda etken olabileceğini düşünmelerinin nedenleri; ölen kişilerin ruhlarının geriye dönebileceklerine olan inançtır. Geriye dönen ruhlar, tıpkı insanlar gibi iyi ve kötü olabilirler (Haviland, 2008: 651). Bu uygulama hem kanlı hem kansız kurban ritüelini içinde barındıran bu uygulamada amaç kötü ruhlardan korunmaktır. Yaşam eşiği olarak görülen yedi yaşına kadar erkek çocuğun saçının kız gibi uzatılması, elbise giydirilmesi, küpe takılması, yüzüne kara çalınması, yıkanmaması ve benzeri uygulamalardaki örtük mesaj, Şamanizm inancının uzantısı olarak kara iyeleri/İslami bakış açısı ile ölüm meleğini kandırma düşüncesinin iç içe geçmesidir. Yine adakta bulunmak için türbenin seçilmesi mekân olarak İslamî iken, ölen ataların ruhlarını memnun ederek onlardan koruyuculuk beklemek Şamanizm ile ilişkilidir. Kültürel bellekte ataerkil sistemde erkek çocuğun daha işlevsel olduğu gerçeği beraberinde erkeğe, kız çocuğundan daha çok nazar değeceği bir başka ifadeyle daha çok sakınılması gerekliliğini ortaya çıkarmıştır. Buna karşın çocuksuzluk olgusuna bağlı olarak hem erkek hem de kız çocuğun türbeye adandığı Satı ve Satılmış gibi her iki cinsi niteleyen adların verildiği bilinmektedir. Bu uygulama gerek Türk dünyası coğrafyasında gerekse Anadolu'nun bazı bölgelerinde hâlâ canlı olarak devam etmektedir. Örneğin Taşova'da "Çocukları olmayan veya doğduktan sonra yaşamayan aileler, kutsal saydıkları tekke türbe ve ziyaret yerlerine giderek adak adarlar; dileklerde bulunurlar. Bu ziyaretten sonra çocukları olursa adını Satılmış veya Satuk; kız olursa Satı koyarlar. Çocuğun adını Satılmış, Satuk veya Satı koyduklarında ziyaret ettikleri tekkeye satılmış kabul ederler. Böylece çocuğun uzun yaşayacağını umut etmektedirler. Ayrıca aileye ve çocuğa musallat olan kötü ruhların çocuğun başkasına ait olduğunu zannederek zarar vermeyeceğine dolayısıyla çocuğun ve ailesinin korunacağına inanılmaktadır” (Düzgün ve Polat, 2019: 203).

\section{Orta Asya'da Saç Adağı âdetinin izleri: Kötü ruhları/ Kara İyeleri kandırmak}

Gerek Orta Asya'da gerekse Anadolu'da saç adağı ritüelinin izine rastlamak mümkündür. "Her seferinde kız çocuğu olan fakat erkek çocuk isteyen Kırgızlar, kızlarına Erkin gibi erkek adı verir; erkek elbisesi giydirir, yanlarına bıçak, silah vb. asarlar, böylece bundan sonra erkek çocuk olacağına inanılır. Erkek çocukları olup da yine erkek çocuk isterlerse çocuğun adını, devam etsin arkası gelsin anlamına gelen 'Ulan' koymaktadırlar” [1]. Ad verme geleneği üzerinden ataerkil sisteme gönderme yapan bu uygulamadaki yöntem, benzerin benzerini getireceği düşüncesiyle taklit etme bir başka ifadeyle sempatik büyüdür.

Y. Kalafat’ın açıklamasına göre "Karailerde korumanın yollarından biri kötü ruhları yanıltmaktır. Türkmen ve Kırmanç inançlarında erkek çocuğu yaşamayan aile, erkek çocuğuna kız elbisesi giydirir. Böylece, erkek çocuğa zarar verecek Kara İye, şaşırtılıp ondan kurtulmuş olunur. Aynı maksatla erkek çocuğun saçı uzatılarak ona kız süsü verilir [2]. Kalafat'ın toplumsal cinsiyet odağında burada vurguladığı tam da çalışmadaki savla birebir ilgilidir. Erkeğin kız gibi gösterilerek kötü ruhlardan

\footnotetext{
RumeliDE Dil ve Edebiyat Araştırmaları Dergisi Osmanağa Mahallesi, Mürver Ciçeği Sokak, No:14/8 Kadıköy - İSTANBUL / TÜRKIYE 34714 e-posta: editor@rumelide.com tel: +90 $5057958124,+902167730616$ 
korunması yani erkeğin hayatta kalabilmesi bir başka cinse ait fiziki görünümle mümkün olabilmesi toplumun cinsiyete yüklediği anlamla açıklanabilir. Cinsiyete bağlı fiziki görünüm, giyim kuşam ve benzeri durumların kültürel olduğu düşünüldüğünde, kötü ruhların da toplumda işlevsel olabileceğini ortaya koymaktadır. Kalafat'ın devamında söyledikleri de aynı doğrultudadır: Kara İye, sadece o toplumun dilini biliyor kabul ediliyor olmalı ki, yaşamayan çocuğun ailesi Kara İyeler'den korunmak için, çocuğa başka bir dilden isim koyar. Feriştah’tan veya cinlerden çocukların korunması için, onlara çirkin isimle, köpek türünden hayvan isimleri, çör-çöp gibi isimler konulur. Çocuk dünyaya gelirken, o anda kapının önünden geçen hayvanın isminin konulduğu da olur [2]. Hazarlarda yaşamayan erkek çocuklarına entari giydirilir, küpe takılır. Bazı ailelerde, erkek çocukları öldükleri için, erkek çocuklarının ismini kötü bir şeyin ismini koyarlar. Örneğin Çalme, Hazara dilinde tezek demektir [2]. Uygur Türklerinde, art arda kız çocukları olanlar, erkek çocukları olması için kız çocuklarına erkek ismi koyarlar. Örneğin; Oğulhan, Oğulnisahan... Eğer doğan çocuklar yaşamamışsa, son doğan bebeği ister kız ister erkek olsun, isminin başına "Tur" getirilerek ad verilir. Örneğin; Turdi, Tursungül, Turdi Muhemmet, Turnisa, vb. (Tursinniyaz'dan akt. Öger, 2012: 1690-1691). Uygur Türkleri arasında isim verme geleneği ile ilgili önemli uygulamalardan biri de şöyledir: "Hamile kadının sürekli düşük yapması ya da doğumunun ardından bebeğinin kısa sürede ölmesi gibi nedenlerle bir türlü çocuk sahibi olamayan kadınlar, bebek dünyaya getirdiğinde çocuğa Allah Berdi, Huda Berdi, İgem Berdi, Sitvaldi, Tilivaldi, Turdi, Turğun, Tursun, Turnisahan gibi isimlerden birini koymaktadır. Ayrıca uzun zaman sonra kavuşulan erkek bebeğin uzun ömürlü olması için halk arasında "selilek" denilen "niyaz saçı” bırakma geleneği vardır" (Rahman'dan akt. Öger, 2012: 1691). Uygurlarda "niyaz saçı” olarak tesadüf edilmektedir. "Niyaz, yalvarmak demektir. Bu, Allah'tan dilenen ve onun da bahşettiği çocukların nişanesi olarak, erkek çocukların başının arka kısmında "niyaz saçı" bırakıp, bunu üç kısma ayırarak bunlardan bir tane belik örmek demektir. Niyaz saçını, çocuk yedi yaşına girdiğinde bir törenle kesmek gerekir. Böyle yapıldığında çocukların erken ölmekten kurtarıldığına inanılmaktadır" (Ürümçi’den akt. Öger: 1691). Bu örnekleri Orta Asya Türk kültür coğrafyasında çoğaltmak elbette mümkündür. Burada dikkat çeken durum, özellikle erkek çocuğunun yaşam eşiği olarak görülen yedi yaşına kadar şeklen dahi olsa "kız gibi” gösterilme düşüncesidir. Bu inanış, kötü iyelerin kız görünümündeki erkek çocuğu fark edemeyeceği ve böylece ona zarar veremeyeceği yönündeki düşünceden, kötü ruhların kızlardan çok erkeklere zarar verebileceğinden ya da ataerkil sistemde erkeğin yaşamasının kıza göre daha hayati görülmesinden kaynaklanabilir.

Abdülkadir İnan, erkek çocuğu yaşamayan ailelerin çocuklarının yaşamaları için onlara kız isminin konulduğunu, kız giysilerinin giydirildiğini, saçlarının uzatıldığı ve küpe takıldığg bilgisini aktarır. Sadece erkek çocukların ölümüne sebep olan güçleri bu yöntemle aldatmak amaçlanmıştır. Çocuklara yaşamaları için çirkin isimler konulması da onların beğenilmemesini sağlamak içindir. Bazen de çocuklar özellikle pasaklı tutulur, yüzüne kömür sürülür veya bezendikleri zaman kem sakınılır. Bununla amaç çocuğu görünen ve görünmeyen nazar türünden tehditlerden muhafaza etmektir. Güçlü hayvanların isminin konulmasında da amaç aynıdır (İnan, 1991). İnan’ın "ölüme sebep olan gücü aldatmak” şeklindeki ifadesini Şamanizm inancının etkisiyle kara iyeleri, İslamiyet'in etkisiyle de Azrail’i kandırmak şeklinde yorumlanabilir. Hakikatte İslamî inanışta Azrail’i kandırmanın mümkün olmadığı bilinse de böyle bir uygulamanın altında kötü ruhlarla yapılan mücadelenin senkretize formunun yattığı söylenebilir.

\section{Anadolu'da saç adağı âdetinin izleri: Ölüm meleği Azrail’i kandırmak}

Anadolu’ da günümüzde saç adağı izine hâlâ rastlamak mümkündür. Kalafat, kötü ruhları kandırmaya yönelik düşünceyi açıkça ortaya koyar: "Ağrı ve çevresinde çocukları yaşamayan aileler, doğan

\footnotetext{
\begin{tabular}{r|l} 
Adres & Address \\
RumeliDE Dil ve Edebiyat Araşttrmaları Dergisi & RumeliDE Journal of Language and Literature Studies
\end{tabular} Osmanağa Mahallesi, Mürver Çiçeği Sokak, No:14/8 Osmanağa Mahallesi, Mürver Çiçeği Sokak, No:14/8 Kadıköy - İSTANBUL / TÜRKIYE 34714 Kadıköy - ISTANBUL / TURKEY 34714 e-posta: editor@rumelide.com e-mail: editor@rumelide.com, tel: +90 505 7958124, +90 2167730616 phone: +90 505 7958124, +90 2167730616
} 
çocukları yaşasın diye-özellikle erkek çocuğu yaşamayanlar- onlara, erkekse kız elbisesi; kız ise erkek elbisesi giydirip büyütürler. Erkek çocukların saçları uzatılır, entari giydirilir. Amaç yine, çocuğu kötü ve kara iyelerden korumak, ona dokunmamasını, onu aldatarak erkek çocuğun hayatta kalmasını sağlamaktır. Türk inançlarında çocukları kötü ruhlardan korumak amacıyla verilen adlar arasında Satuk, Satılmış, Duran, Dursun, Yaşar, Durdu sayılabilir" (Kalafat, 1996: 95-97). "Ağrı'da yaşaması ümitsiz olan çocuklara büyüyünceye kadar İslamî isimler verilmezdi. İslamî olmayan isimler takarlardı. Çocukların bu şekilde korunacağına inanılırdı. Bu inanç da tipik Türk inancıydı. Amaç, çocuğa fenalık eden kötü ruhu şaşırtmak, yalancı ad ile onu aldatıp fenalıktan gizlemektir" (Kalafat, 1996: 100). "Harput'ta, kız çocukları olduğu halde, oğlan çocuğu olmayan veya doğduğu hâlde çocuğu yaşamayan kadınlar, oğlan çocuğuna kavuştukları zaman, yedi yaşına kadar çocuğun saçlarını uzatır, örer ve kendisine bu zaman içinde kız elbisesi giydirirler. Ters giyme adı ile bilinen bu uygulamanın değişik bir biçimi de yedi yll boyunca kullanılmamış (haşıllı) elbisenin giydirilmemesidir. Komşu ve akrabalardan alınan eski, yamalı, hatta yırtık elbiselerini kullanarak, yedi yıl boyunca hayatta kalmayı başaran oğlan çocuğundan sonra doğacak olan bebeklerin artık yaşayacağına inanılır. Bu tür çocukların, belirlenen süre içinde uzun süren bir hastalığa yakalanmaları hâlinde ise adları değiştirilir. Bu inançlarda çocuğa ölmüş süsünün verilerek ölüm ruhunu şaşırtma amacı vardır (Araz, 1995 akt. Tokur: 2004). "Erzincan ve Erzurum'da çocuğu olup da yaşamayan kimseler, çocuklarına ölmesin, yaşasın anlamında Yaşar, Dursun, Durak, Durdu gibi adlar verir. Sürekli kız çocuğu doğuran erkek çocuk arayan kişiler, son doğan kızlarına Döne, Döndü adını verir. Bununla erkek çocuğa dönüleceğine inanılır" (Kalafat, 1996: 99). Adana'da kız çocuğu yaşayıp erkek çocuğu ölen kadınlar da yakınlarındaki bir türbeye giderek burada oğlu olursa yedi yaşına kadar saçını kesmeyeceğini, yedi yaşında kurban keserek türbede keseceğini adamaktadırlar. Bu şekilde olan erkek çocuklarının saçları doğumlarından itibaren kesilmeyip, adak adanmış olan türbede kurban kesildikten sonra, dualar eşliğinde kesilmektedir. Bu kesilen saç da türbenin duvarına asılmaktadır (Çağımlar, 2). Nevşehir, Avanos’ta bu gelenek şöyledir:

Babamın halası beş doğum yapmış. Dünyaya getirdiği çocukların hepsi de bir yaşına gelmeden ölmüşler. Altıncı çocuğu oğlan olmuş, adını Duran koymuşlar. Bunun da hayatından endişe edildiğinden yaşaması için kim ne derse, yol gösterdi ise yapmışlar. Duran'a yedi yıl banyo yaptırılmamış, öyle ki her yanı kirden kerme bağlamış, sadece yüzü soğuk su ve sabunlu bir bezle silinmiş. Evinde Mehmet ismi olan yedi evden parça bez toplanarak çocuğa gömlek ve yorgan yapılmış, yedi evden gümüş parçası toplanarak bilezik yapılmış, çocuğun annesinin sağ el bileğine takılmış. Çocuk uyumadan önce babaannesi tarafından her zaman okunmuş (Örnek, 1979: 115).

Ölme ihtimali olan çocuğun yaşamasını sağlamak amacıyla yapılan pratiklerden biri de "satılma âdeti"dir. İçel'de, kadının doğurduğu yaşamıyorsa daha önce anlaştığı bir aileye, bilhassa hiç çocuğu bir aileye çocuğunu doğar doğmaz satar. Bunun kötü ruhları kandırmak için "Ben bu çocuğu sattım, benim değil, almayın elimden”, diye düşünür (Örnek, 1979: 127).

Tunceli'de çocuğu yaşamayanlar yedi yaşına kadar çocuğun saçını kesmezler. Çocuk yedi yaşını bitirirken kimisi bir kurban, kimisi yedi kurban alarak ya evinde akraba ve komşularını çă̆ırarak veya ziyarete götürerek saçı da kurbanı da keser. Normalde ise çocuk bir yaşına geldi mi ufak bir eğlence ile saçı kesilir (Örnek 1979: 197). Görüleceği üzere Anadolu'nun muhtelif bölgelerinde erkek çocuğu isteme, doğan erkek çocuğunun yaşamasını sağlama amacıyla başvurulan pratiklerin birçoğu Orta Asya'daki uygulamalarla benzerlik göstermektedir. Hem kız hem erkek çocuğunun yaşaması için pratikler mevcuttur, fakat kızla ilgili olanlar erkeğe görece daha azdır. Ritüelin kökeninde, erkek çocuğunu yaşam eşiğine kadar kız gibi göstererek kara iyeleri ya da Azrail'i şaşırtma, aldatma vardır.

\footnotetext{
RumeliDE Dil ve Edebiyat Araștırmaları Dergisi Osmanağa Mahallesi, Mürver Ciçeği Sokak, No:14/8 Kadıköy - İSTANBUL / TÜRKIYE 34714 e-posta: editor@rumelide.com tel: +90 $5057958124,+902167730616$ 


\section{Toplumsal cinsiyet stereotipleriyle geleneğin çatışması: Saç Adağı âdeti}

Çalışmada ele alınan ve olayın Hatay'da gerçekleştiği anlaşılan, 18 Kasım 2008 tarihli Hürriyet Gazetesi’nde çıkan "Saç Uzatma Adağı Mehmet Ali'nin Sıkıntısı Oldu" başlı̆̆ını taşıyan haber, çatışmanın örneklemidir. Haberin içeriğinde "geleneğin bireyleri sıkıntıya sokması, uygulamanın ekonomik ve ritüelistik boyutu, erkek çocuğun görünümünden dolayı bu ritüeli bilmeyenlerce ilk başta kız sanılması, sorgulanması ve çocuğun bir an önce saçlarından kurtulmak istemesi” söz konusudur. Dikkati çeken durum, pratiğin hem kız hem erkek çocuğu için yapılırken erkek çocuğun toplumsal cinsiyet algısından dolayı görünümü ve yaşadıklarıyla gündeme gelmesidir. Konunun haber değeri taşıması geleneğin, toplumun genelince bilinmemesinden/unutulmasından ve toplumsal cinsiyet algısıyla ritüelin çatışmasından kaynaklanmaktadır. Geleneğin içinde yetişenlerce uygulamanın sorgulanması düşünülemez. Çünkü "Bunu neden böyle yapıyorsun?" sorusuna verilecek yanıt; "atalarımızdan böyle geldiği ve böyle gördüğümüz için” olacaktır. Bu yönüyle haberin eleştirel olduğu söylenebilir. Ayrıca erkeğin kız gibi saçının uzatılması, özellikle çocuğun gelişimi için kritik dönem olan kimlik ve aidiyet duygusunun geliştiği 3-6 yaşında olması tartışmanın sosyo-psikolojik açıdan başka bir yönüdür. Maddi imkansızlıklardan dolayı adak kurbanı kesilemeyen Mehmet Ali ve onun gibi toplumsal cinsiyet algısına yönelik sıkıntı yaşayan başka kişilerle yapılacak daha kapsamlı görüşmeler, sosyo-psikolojik açıdan eleştirilere yanıt verebilir. Okula başlamadan önce daha dar bir çevrede yaşayan ve çevresindekilerin adaklı olma kültür kodunu bildiği Mehmet Ali’nin o çevreden çıkı geleneğin kodunu bilmeyen kişilerin olduğu farklı bir ortama girmesiyle konu toplumsal cinsiyet odağında medyada gündeme gelmiştir. Annesi, bu süreci şu şekilde aktarmıştır: "Allah'a dua ederek, bir çocuğum olursa 7 yaşına kadar saçlarını kestirmeyeceğim. Daha sonra koyun kesip tören düzenleyerek, davul zurnalı bir tören yapacağım. Adağımın ardından bir yıl geçmesinin ardından hamile kaldım ve bir kız çocuğu dünyaya getirdim. Onun saçlarını süre dolana kadar hiç kesmedim ve daha sonra koyun kesip tören düzenleyerek adağımı gerçekleştirdim.” [3]. Kızını kucağına almasından iki yıl sonra tekrar hamile kaldığını ve Mehmet Ali'yi dünyaya getirdiğini belirten anne Recimoğlu, oğlunun saçını da kızınınki gibi kestirmediğini kaydeder. Saçlarıyla ilgili bugüne kadar herhangi bir şikâyette bulunmayan Mehmet Ali'nin okula başlamasıyla rahatsız olduğunu vurgulayan anne, "Oğlum renkli gözlü ve uzun saçlı olunca öğretmenleri ve arkadaşları ilk bakışta onu kız zannediyor. Mehmet Ali de bu duruma üzülüyor. Bu yüzden bir an önce saçlarından kurtulmak istiyor” diye konuştu. Oğlunun saçlarını koyun adayarak ve tören düzenleyerek okula başlamadan önce kestirmeyi düşündüklerini, ancak maddi imkânsızlıklar nedeniyle kurban alamadıkları için bunu yapamadıklarını anlatan anne Recimoğlu, parayı en kısa sürede denkleştirip Mehmet Ali'yi okulda yaşadığı sıkıntıdan kurtarmak istediğini kaydetti [3]. Annenin "Saçlarılya ilgili bugüne kadar herhangi bir şikâyette bulunmayan Mehmet Ali'nin okula başlamasıyla rahatsız olduğunu”na yönelik söylem, bağlamın değişmesiyle ritüellerdeki toplumsal cinsiyet algısının da değiştiğini ortaya koymaktadır. Kenny ve Smillie, bağlamın toplumsal cinsiyet algısı üzerindeki değişimini katılımcı gözlemci olarak çocuklar üzerinden araştırır. Mahallede görüşen kız erkek çocukların okulda görüşmediklerini fark eder ve bunun nedenini çocuklara sorar. Çocuklar ona: "Biz mahallede ve kilisede arkadaşız ama okulda birbirimizi tanımıyor gibi yapıyoruz, böylece bizimle dalga geçmiyorlar” (2017: 202) derken, bağlamın erkek ve kız çocukların sosyal ilişkilerini nasıl etkilediğini örneklendirir. Bu durum, çevrenin erkek ve kadın ilişkisini daha çocukken denetlediğini göstermektedir. Kenny ve Smillie, "Okulun dinamiğinin mahallenin dinamiğinden farklı olmasıyla, çocukların birbirini tanımlama biçimleri de değişmektedir" (2017: 202) şeklinde durumu açıklar. Thorne ise pembe oje sürülen küçük çocuğa dair tartışmayı ve okulda yanlışlıkla kızların sırasına giren erkek öğrenciyle arkadaşlarının dalga geçmesi örneğini verir (Kenny ve Smillie 2017: 201-202). Tıpkı pembe oje sürülen ya da kızların sırasına yanlışlıkla oturduğu için toplum, aile ve arkadaş çevresi tarafından dalga geçilen ve istendik davranış ve görünüş kazanması 
için denetlenen bu örneklerde olduğu gibi Mehmet Ali de sınıf arkadaşları ve çevresi tarafından toplumsal cinsiyet odaklı dış baskıya maruz kalmıştır. Toplumsal cinsiyet kimliği ve davranışı kazanma açısından kendi cinsini tanımaya başladığı bu dönemde onun yaşadıkları habere konu olacak kadar dikkat çekmiştir. Fakat konunun medyaya taşınması ritüelin sosyo-psikolojik yönü değil ekonomik boyutuyla ilgilidir. Mehmet Ali ise, "Saçları uzun olduğu için arkadaşlarının kendisini ilk bakışta kız zannettiğini, saçlarının uzun olmasına üzüldüğünü, diğer erkekler gibi kısa saçlı olmak istediğini söyler. Özellikle yaz aylarında saçlarının kendisini çok rahatsız ettiğini belirten Mehmet Ali, annemle kıyafet almaya gittiğimizde herkes beni kız zannettiği için önce etek ya da elbise veriyorlar, annem durumu anlatınca erkek kıyafetlerini çıkarıyorlar. Ben bu durumdan artık çok sıkıldım. Bir an önce bu saçlardan kurtulmak istiyorum” [3] diyerek toplumsal cinsiyet odağında yaşadığı sıkıntıyı dile getirir. Mehmet Ali’nin "diğer erkekler gibi” giyinmek istemesine yönelik talebi, yaşadığı toplumda cinse bağlı olarak genel geçer giyim kuşama dair beklendik kültür kodunu ifade etmektedir.

Konunun ikinci sözlü kültür ortamında da eleştirildiği ve tartışıldı̆̆g görülmektedir: "Yani, bu insanlar adak parasını bulana kadar çocukları belki de üç metre saç sahibi olacak. Aferin size... Çocuğun hayatı değil, senin tuhaf düşüncen önemli çünkü ebeveyn.” [3] diyen kişi geleneği, aslında sosyo-psikolojik açıdan eleştirmekte ve bu bakımdan geleneğin bağlamla ve ritüelle ilişkisini göz ardı etmektedir. Bir başka kişi bu eleştiriye bağlam ve ritüel ilişkisi özelinde yanıt verir: "Benim böyle adaklı olan ve şu an yirmili yaşlarında tanıdığım insanlar var ve psikolojileri hiç etkilenmedi çünkü farklı olanın dışlanmadığı bir toplumda yaşıyorlar” [3]. Her iki yorumcunun aykırı fikri, ritüeli bağlamında tecrübe etmekle dışarıdan gözlemlemekten kaynaklanmaktadır. Mehmet Ali'nin toplumsal cinsiyet odaklı yaşadığı sorun, kendi yaşadığı çevreden değil, sonradan içine dahil olduğu farklı ortamdan kaynaklanmaktadır. Erkek ya da kız çocuklarının nasıl giyinmesi, görünmesi hatta ne renk giyinmesi gerektiğine dair beklentiler, saç adağı ile çeliştiğinden konu medyanın gündemine gelmiştir.

\section{Sonuç}

Bireyin doğuştan gelen fizyolojik, genetik ve biyolojik özelliklerinin dışında değerlendirilen toplumsal cinsiyet kavramı toplum belleğinde birey dünyaya gelmeden belli kalıplarla var olmakta, erkeklik ve kadınlık içine doğulan toplumda bireye sonradan öğretilmektedir. Bu durum kültürler arası farklılık gösterir. Sözlü anlatmalar, gelenek ve ritüeller toplumsal cinsiyetle ilişkilendirilebilir. Birey, ilk olarak içine doğduğu toplumun, cinsiyet stereotipleri ile karşılaşır. Bireyin nasıl davranması ve şeklen nasıl giyinmesi, bedensel hareketleri ve görünümünün nasıl olması gerektiği gibi birçok kültürel kod, içgüdüsel etkenlere bağlı olarak bireye öğretilir. Örneğin, erkek çocuğun giyeceği kıyafet, rengi ya da saç uzunluğu önceden bellidir. Bu açıdan erkek çocuğunun "kız gibi" görünmesi toplumsal cinsiyet tartışmasının merkezinde durmaktadır. Zira kızın saçının uzun, erkeğin kısa olması gerektiği bilgisi istendik bir davranıştır. Fakat, halk pratiklerinden biri olan saç adağında erkek çocuğun yedi yaşına kadar kız gibi saçının uzatılması ve giydirilmesi söz konusudur. Gerek Orta Asya gerekse Anadolu'nun bazı bölgelerinde hâlâ uygulanan saç adağı âdeti, toplumsal cinsiyet kavramı özelinde "yaşamayan erkek çocuğun yaşamasını sağlamak" amaçlı bir pratiktir. Erkek çocuğunun hayatta kalmasının istenmesinin altında yatan ana neden, soyun devamı yani ataerkil sistemdir.

Erkek çocuk isteyen ya da doğan erkek çocuğu yaşamayan aileler, çocuklarının yaşaması için adakta bulunur. Buna göre çocuk yedi yaşına kadar saçı kesilmez ve kız gibi giydirilir. Nihayetinde yedi yaşına gelince saçıyla birlikte kurbanı da kesilir. Kanlı ve kansız kurban ritüelini barındıran bu uygulamada dikkat çeken husus, erkek çocuğun hayata tutunmasını saylayan şeyin bir başka cinse ait görünümdür. Ataerkil sisteme bağlı olarak erkek çocuğuna kız çocuğundan daha çok nazar değeceği inanışı

\footnotetext{
RumeliDE Dil ve Edebiyat Araștırmaları Dergisi Osmanağa Mahallesi, Mürver Ciçeği Sokak, No:14/8 Kadıköy - İSTANBUL / TÜRKIYE 34714 e-posta: editor@rumelide.com tel: +90 505 7958124, +90 2167730616

Address

RumeliDE Journal of Language and Literature Studies Osmanağa Mahallesi, Mürver Çiçeği Sokak, No:14/8

Kadıköy - ISTANBUL / TURKEY 34714

e-mail: editor@rumelide.com,

phone: +90 5057958124 , +90 2167730616
} 
beraberinde onu kötü ruhlardan/ölüm meleğinden korumaya yönelik pratik geliştirilesine neden olmuştur. Bu uygulamanın temelinde Şamanizm etkisiyle ölmüş ataların ruhlarını memnun ederek kara iyeleri, İslamiyet'e göre ise ölüm meleği Azrail’i kandırarak çocuğun hayatta kalmasını sağlamak yatmaktadır, fakat gelenek ve kültür kodu bilinmediğinde, farklı uygulamalar marjinal kabul edilerek eleştirilir. Toplumsal cinsiyete dair beklentiler, sosyal normları denetler ve bu durum kimi zaman geleneğin sürekliliğini engeller.

Erkeklik ya da kadınlığın toplum tarafından bireye sonradan öğretildiği göz önünde tutulduğunda, cinsiyet ve ritüel ilişkisine dair tartışmaların bağlamla ilişkili olduğu söylenebilir. Geleneğin bilindiği ve icra edildiği bir ortamda erkek çocuğun kız gibi görünmesi ve giyinmesi sorun teşkil etmezken, geleneğin bilinmediği bağlamda ise ritüelin sorgulandığı hatta haber değeri taşıyarak gündeme geldiği belirlenmiştir. $\mathrm{Bu}$ durum toplumsal cinsiyet kavramının bağlamla ilişkisinin önemini ortaya koymaktadır. Çalışmada ele alınan örneklemde toplumsal cinsiyet tartışmasının, ritüel kodunun bağlamda bilinmemesinden kaynaklandığı tespit edilmiştir. Ayrıca geleneğe yöneltilen sosyopsikolojik temelli eleştirilerin yanıtı, ritüele dahil olan ve şimdi yetişkin olan erkeklerle yapılacak görüşmelerle belirlenebilir. Elbette bireyin gelişimi için kritik dönem olan 3-6 yaşta bu ritüelin uygulandığı erkek çocukların cinsiyet, kimlik ve aidiyet gibi sorunlar yaşayıp yaşamadıkları uzun dönem ve kapsamlı bilimsel araştırmalar neticesinde öğrenilebilir. Ritüellerin toplumsal cinsiyet kültür kodunu barındırdığı, aykırı örneklerde ritüelin sorgulandığı ve bu durumun geleneği besleyen dinamiklerin ortadan kalkmasına neden olduğu, bağlamın toplumsal cinsiyet tartışmalarında önemli bir işleve sahip olduğu tespit edilmiştir. Çocuksuzluk olgusuyla iç içe olan bu ritüelde, günümüzde geleneğin herkes tarafından bilinmemesi, iletişim teknolojisinin gelişmesi, çocuksuzluk durumunda modern tıbba başvurma eğilimi, kentleşme, çocuk gelişimi hakkındaki farkındalık ve eğitim gibi birçok etken, geleneğin sorgulanmasina ve eleştirilmesine neden olmakta ve konuyu toplumsal cinsiyet tartışmaları odağına taşımaktadır.

\section{Kaynakça}

Araz, R. (1995). Harput’ta Eski Türk İnançları ve Halk Hekimliği. Atatürk Kültür Dil ve Tarih Yüksek Kurumu, No: 108. Ankara: Atatürk Kültür Merkezi.

Aydın, F. (2019). “Uygur Halk Anlatılarında Sayı Simgeciliği”, Karadeniz Uluslararası Bilimsel Dergi, Volume: 44, Winter-2019, p. (209-227).

Bates, D. G. (2013). 21.Yüzyılda Kültürel Antropoloji İnsanın Doğadaki Yeri. Türkçe Çeviri Editörü: Suavi Aydın. İstanbul: İstanbul Bilgi Üniversitesi.

Bekki, S. (1996). Türk Mitolojisinde Kurban, Akademik Araştırmalar 3 : 16-28.

Berktay, F. (2014). Tektanrılı Dinler Karşısında Kadın. İstanbul: Metis.

Çağatay, S. (1974). Türklerde Batıl İnançlar Arasında Tabu. I. Uluslararası Türk Folklor Semineri (Bildiriler). Ankara. 37.

Çağımlar, Z. "Adana'da Çocuğa Bağlı İnançlar ile Bunlara Bağlı Pratiklere Genel Bir Bakış"http://turkoloji.cu.edu.tr/CUKUROVA/makaleler/zekiye_cagimlar_adana_cocuk.pdf erişim tarihi: 10.01.2015.

Durkheim, E. (2019). Dinî Hayatın İlk Biçimleri. Çev. Yasin Aktay ve Kenan Çapık. İstanbul: Ataç.

Düzgün, F. G. ve K. Polat (2019). "Taşova ve Çevresinde Ad Verme Geleneği ve "Satılmış" Adı", Avrasya Sosyal ve Ekonomi Araşttrmaları Dergisi. Cilt 6 Sayı 8 Yll 2019, s. 196-207.

Emiroğlu, K. ve Aydın, S. (2020). Antropoloji Sözlüğü. İstanbul: Islık.

Ergun, P. (2019). Sibirya Türklerinin Destanlarında İyeler. Konya: Kömen.

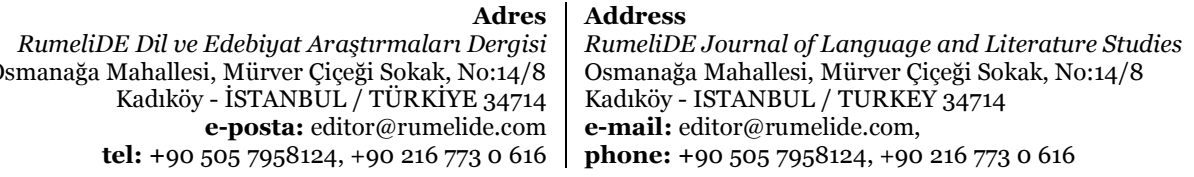


Eriksen, T. H. (2012). Küçük Yerler Büyük Meseleler Sosyal ve Kültürel Antropoloji. Çev. A. Erkan Koca. Ankara: Birleşik.

Ersoy, E. (2009). Cinsiyet Kültürü İçerisinde Kadın ve Erkek Kimliği (Malatya Örneği)" Frrat Üniversitesi Sosyal Bilimler Dergisi C.19. Sayı: 2, Sayfa: 209-230. Elazığ.

Haviland, W. A. vd. (2008). Kültürel Antropoloji. Çev. İnan Deniz Erguvan Sarığlu. İstanbul: Kaknüs. İnan, A. (1976). Eski Türk Dini Tarihi. İstanbul: Kültür Bakanlığı.

İnan, A. (1991). Makaleler ve İncelemeler. Ankara: Türk Tarih Kurumu.

Kalafat, Y. (1996). Doğu Anadolu'da Eski Türk İnançlarmın İzleri. Ankara: Atatürk Kültür Merkezi.

Kenny, M. G. ve Smillie, K. (2017). Antropolojïye Giriş. Çev. Soner Torlak. Ankara: Dipnot.

Marshall, G. (1999). Sosyoloji Sözlüğü. (Çev. Osman Akınhay-Derya Kömürcü). Ankara: İlim ve Sanat.

Maruani, M. (2011). Sosyolojik Düşünce Sözlüğ̈̈. Hzl. Massimo Borlandi, Raymond Boudon, M. Cherkaoui, Bernard Valade. Çev. Bülent Arıbaş. İstanbul: İletişim.

Öger, A. (2012) Uygur Türklerinde Doğum Âdetleri. Turkish Studies - International Periodical For The Languages, Literature and History of Turkish or Turkic Volume 7/1 Winter. p.1679-1694, Turkey. s.1679-1694.

Örnek, S. V. (1979). Geleneksel Kültürümüzde Çocuk. Ankara: Türkiye İş Bankası Kültür.

Örnek, S. V. (2017). Etnoloji Sözlüğ̈̈. Ankara: BilgeSu Yay.

Schimmel, A. (2000). Sayıların Gizemi, Çev. Mustafa Küpüşoğlu. İstanbul: Kabalcı.

Türköne, M. (1995). Eski Türk Toplumunun Cinsiyet Kültürü. Ankara: Ark.

[1] http://omarkosger.blogcu.com/kirgiz-halk-inanclari/4395084; erişim tarihi 10.01.2015.

[2] Kalafat Yaşar; http://www.kulturelbellek.com/ad-verme-gelenegi/; erişim tarihi 10.01.2015.

[3] http://www.hurriyet.com.tr/gundem/10384707.asp; erişim tarihi 11.04.2015.

RumeliDE Dil ve Edebiyat Araștırmaları Dergisi Osmanağa Mahallesi, Mürver Ciçeği Sokak, No:14/8 Kadıköy - İSTANBUL / TÜRKIYE 34714 e-posta: editor@rumelide.com tel: +90 505 7958124, +90 2167730616
Address

RumeliDE Journal of Language and Literature Studies Osmanağa Mahallesi, Mürver Çiçeği Sokak, No:14/8

Kadıköy - ISTANBUL / TURKEY 34714

e-mail: editor@rumelide.com,

phone: +90 505 7958124, +90 2167730616 